\title{
IDENTIFIKASI SAKARIN PADA ES KELAPA MUDA YANG DIJUAL DI PASAR RAJAWALI KOTA PALANGKA RAYA
}

\author{
Identification of Saccharin in Coconut Beverage from Rajawali Market Palce in \\ Palangka Raya
}

\section{Guntur Satrio Pratomo'*}

2Dosen Program Studi D-III Farmasi, Fakultas Ilmu Kesehatan, Universitas Muhammadiyah Palangkaraya, Palangka Raya, Kalimantan Tengah

*email: pratomo.guntursatrio@gmail.com

\begin{abstract}
Abstrak
Sakarin merupakan golongan bahan tambahan pangan yang diizinkan oleh Peraturan Menteri Kesehatan Republik Indonesia Nomor 33 Tahun 2012 untuk digunakan dalam minuman, namun apabila dikonsumsi secara berlebihan dapat menyebabkan dampak yang berbahaya bagi kesehatan seperti menimbulkan alergi dan penyakit kanker kantung kemih. Tujuan dalam penelitian ini adalah untuk mengetahui adanya sakarin pada minuman es kelapa muda yang dijual di Pasar Rajawali Kota Palangka Raya. Sampel yang digunakan sebanyak 5 sampel dan teknik pengambilan sampel secara sampling jenuh. Pemeriksaan sakarin dilakukan secara kualitatif dengan menggunakan metode resorsinol. Dari hasil penelitian yang telah dilakukan menunjukkan bahwa semua sampel minuman es kelapa muda yang telah diperiksa negatif mengandung pemanis sakarin.
\end{abstract}

Kata Kunci:

Sakarin

Es Kelapa Muda

Resorsinol

Keywords:

Saccharin

Coconut lce

Resorcinol

\section{Abstract}

Saccharin is a class of food additives permitted by Indonesia Republic Minister of Health Regulation No. 33 of 2012 for use in drinks, but if consumed in excess can cause harmful effects on health such as causing allergies and bladder cancer. The purpose of this study was to determine the presence of saccharin in coconut ice drinks in Pasar Rajawali Kota Palangka Raya. The sample used was 5 samples and the sampling technique was saturated sampling. Saccharin examination is done qualitatively using the resorcinol method. From the results of research that has been done shows that all samples of coconut ice drinks that have been tested negatively contain saccharin sweeteners. (C) year The Authors. Published by Institute for Research and Community Services Universitas Muhammadiyah Palangkaraya. This is Open Access article under the CC-BY-SA License (http://creativecommons.org/licenses/bysa/4.0/). DOI: https://doi.org//0.33084/jsm.vxix.xxx.

\section{PENDAHULUAN}

Secara umum kesehatan merupakan hal yang paling utama yang sangat diperlukan dalam diri setiap orang dan juga merupakan faktor utama penentu kelangsungan hidup kita. Tanpa adanya kesehatan, seluruh aktivitas yang akan kita lakukan tidak akan berjalan dengan lancar. Kesehatan juga sangat berhubungan dengan pangan. Pangan merupakan kebutuhan manusia yang sangat mendasar karena berpengaruh terhadap ekstensi dan ketahanan hidup manusia. Manusia membutuhkan energi untuk menjamin kelangsungan hidupnya. Energi itu sendiri diperoleh dari bahan pangan yang dikonsumsi yang mengandung berbagai zat-zat gizi dalam bahan pangan tersebut mengalami proses metabolisme dalam tubuh sehingga menghasilkan energi untuk beraktivitas'. Menurut Undang-Undang Republik Indonesia Nomor I8 Tahun 2012 tentang Pangan menyatakan bahwa Pangan adalah segala sesuatu yang berasal dari sumber hayati produk pertanian, perkebunan, kehutanan, perikanan, peternakan, perairan, dan air, baik yang diolah diperuntukkan sebagai makanan atau minuman bagi konsumsi manusia termasuk bahan tambahan pangan, bahan baku pangan, dan bahan lainnya yang 
digunakan dalam proses penyiapan, pengolahan, dan / atau pembuatan makanan atau minuman.

Bahan kimia sering digunakan sebagai salah satu jenis bahan tambahan pada makanan dan minuman saat ini. Bahan tambahan adalah bahan yang sengaja ditambahkan atau dimasukkan ke dalam makanan dan minuman untuk mendapatkan kualitas yang lebih baik. Bahan tambahan atau yang disebut dengan zat adiktif pada makanan atau minuman dapat berupa pewarna, penyedap rasa dan aroma, pemantap, antioksidan, pengawet, pengemulsi, pemucat, pengental dan pemanis ${ }^{2}$.

Sakarin mempunyai kemanisan 200-700 kali rasa manis gula tebu, sering digunakan pada soft drink, selai, permen, dan jajanan pasar ${ }^{3}$. Pada konsentrasi tinggi, sakarin akan menimbulkan rasa pahit-getir (nimbrah). Kemanisan sakarin empat ratus kali lebih besar dari kemanisan larutan sukrosa 10\%. Dari hasil penelitian di Kanada, didapat bahwa penggunaan $5 \%$ sakarin dalam ransum tikus dapat merangsang terjadinya tumor di kandung kemih $^{4}$.

Minuman merupakan salah satu contoh produk pangan yang mencampurkan pemanis buatan. Minuman yang mengandung pemanis buatan jenis sakarin dapat menimbulkan dampak negatif bagi kesehatan. Dampak penggunaan sakarin bisa menimbulkan alergi dan penyakit kanker kantung kemih apabila digunakan tidak sesuai dengan kadar yang telah ditentukan ${ }^{4}$.

Es kelapa muda merupakan salah satu minuman yang cukup digemari masyarakat karena aroma dan kelezatannya, selain itu es kelapa muda dijual dengan harga yang terjangkau. Di Kota Palangka Raya belum banyak dilakukan penelitian terhadap kandungan pemanis buatan jenis sakarin, terutama pada minuman es kelapa muda yang dijual di Pasar Rajawali Kota Palangka Raya. Selain itu, pasar ini merupakan salah satu pasar tradisional yang cukup besar di Kota Palangka Raya dan memiliki pengunjung yang ramai setiap harinya. $\mathrm{Hal}$ ini disebabkan karena hampir semua jenis dagangan serta kebutuhan sehari-hari banyak tersedia di pasar ini.
Hasil penelitian Ramadhan (2016) tentang identifikasi sakarin pada minuman es kelapa muda yang dijual di bawah Jembatan Kahayan Kota Palangka Raya yang dianalisa secara kuantitatif dengan menggunakan metode spektrofotometri, dari 4 sampel yang digunakan menunjukkan bahwa keempat sampel tersebut positif mengandung zat pemanis buatan jenis sakarin. Oleh karena itu, tidak menutup kemungkinan bahwa para penjual atau pedagang minuman es.

\section{METODOLOGI}

Penelitian ini dilaksanakan di Laboratorium Kimia Fakultas IImu Kesehatan Universitas Muhammadiyah Palangkaraya. Sampel yang digunakan pada penelitian ini adalah es kelapa muda yang diperoleh dari 5 penjual es kelapa muda diPasar Rajawali Kota Palangka Raya dengan menggunakan teknik pengambilan sampel secara sampling jenuh. Bahan yang digunakan adalah sampel es kelapa muda, baku sakarin, $\mathrm{HCl} 0 \%$, eter, $\mathrm{H}_{2} \mathrm{SO}_{4}$ pekat, $\mathrm{NaOH} 10 \%$, resorsinol, dan aquadest. Alat yang digunakan adalah batang pengaduk, gelasukur, labuukur, erlenmeyer, beaker glass, corongpisah, hot plate, tabung reaksi, rak dan penjepit tabung reaksi, neraca analitik/digital, pipet.

Kelapa muda di Pasar Rajawali Kota Palangka Raya juga menambahkan sakarin pada dagangannya. Salah satu faktor yang menyebabkan para pedagang menggunakan sakarin adalah karena sakarin mudah didapatkan.

Berdasarkan latar belakang di atas, maka peneliti tertarik untuk melakukan penelitian mengenai identifikasi sakarin pada es kelapa muda yang dijual di Pasar Rajawali Kota Palangka Raya dengan mengalisa pemanis sakarin secara kualitatif dengan menggunakan metode resorsinol.

tetes, pipetukur, ball pipet, aluminium foil, botol semprot, dan bunsen.

Pada penelitian ini dilakukan uji kualitatif sakarin pada sampeles kelapa muda diPasar Rajawali Kota Palangka Raya.Analisa uji kualitatif sakarin dengan metode resorsinol dilakukan dengan memipet $50 \mathrm{~mL}$ sampel dan diasamkan dengan $\mathrm{HCl}$ 10\% dengan jumlah berlebih lalu 
diekstraksi I kali dengan $25 \mathrm{~mL}$ eter, setelah terpisah, lapisan eter diuapkan di udara terbuka. Lalu ditambahkan dengan 10 tetes $\mathrm{H}_{2} \mathrm{SO}_{4}$ pekat dan dipindahkan ke dalam tabung reaksi.Kemudian ditambah dengan $40 \mathrm{mg}$ resorsinol, dan dipanaskan secara perlahan - lahan dengan nyala api kecil sampai berubah menjadi warna hijau keruh. Tabung reaksi didinginka lalu ditambah dengan I mL aquades dan I -5 tetes larutan $\mathrm{NaOH}$ 10\%.Bila berbentuk menjadi fluoresensi warna hijau berarti menunjukkan adanya sakarin ${ }^{5}$.

\section{HASIL DAN PEMBAHASAN}

Berdasarkan penelitian yang telah dilakukan, didapatkan hasil Identifikasi Sakarin pada es kelapa muda sebagai berikut:

TabelI. Hasil Uji Kualitatif Sakarin menggunakan metode resorsinol pada minuman es kelapa muda yang dijual di Pasar Rajawali Kota Palangka Raya

\begin{tabular}{|c|l|c|c|}
\hline No & Perlakuan & $\begin{array}{c}\text { Hasil Analisis } \\
\text { Kualitatif }\end{array}$ & Keterangan \\
\hline I & $\begin{array}{l}\text { Kontrol Positif } \\
(+)\end{array}$ & Hijau & Positif (+) \\
\hline 2 & $\begin{array}{l}\text { Kontrol } \\
\text { Negatif (-) }\end{array}$ & Coklat Kehitaman & Negatif (-) \\
\hline 3 & Sampel I & Coklat Kehitaman & Negatif (-) \\
\hline 4 & Sampel 2 & Coklat Kehitaman & Negatif (-) \\
\hline 5 & Sampel 3 & Coklat Kehitaman & Negatif (-) \\
\hline 6 & Sampael 4 & Coklat Kehitaman & Negatif (-) \\
\hline 7 & Sampel 5 & Hitam Kecoklatan & Negatif (-) \\
\hline
\end{tabular}

Penggunaan pemanis buatan di Indonesia masih diizinkan pada makanan dan minuman yang diatur dalam Peraturan Menteri Kesehatan Republik Indonesia Nomor 33 Tahun 2012 tentang Bahan Tambahan Makanan. Jenis pemanis buatan yang diperbolehkan Permenkes yaitu Siklamat, Sakarin, Aspartam dan Sorbitol ${ }^{6}$. Menurut Keputusan Kepala Badan Pengawas Obat dan Makanan Republik Indonesia Nomor 4 Tahun 2014 tentang Batas Maksimum Penggunaan Bahan Tambahan Pangan Pemanis bahwa batas kadar penggunaan harian (Acceptable Daily Intake) siklamat sebanyak 0-II mg/kg berat badan, sakarin sebanyak 0-5 $\mathrm{mg} / \mathrm{kg}$ berat badan, dan aspartam sebanyak 0-40 mg/kg berat badan.
Salah satu pemanis buatan yang diperbolehkan yaitu pemanis sakarin.

Minuman yang mengandung sakarin dapat dikonsumsi dengan batas kadar yang telah ditentukan oleh Kepala Badan Pengawas Obat dan Makanan Republik Indonesia Nomor 4 Tahun 2014 tentang Batas Maksimum Penggunaan Bahan Tambahan Pangan Pemanis yaitu dengan batas maksimum $300 \mathrm{mg} / \mathrm{kg}$, batas maksimum yang dimaksudkan adalah jumlah maksimum Bahan Tambahan Pangan yang diizinkan terdapat pada pangan dalam satuan yang ditetapkan. Apabila melebihi batas kadar yang telah ditentukan akan berdampak menimbulkan alergi dan penyakit kanker kantung kemih. Selain itu, Nasir dan Idris (2018) menyatakan bahwa dampak lain yang ditimbulkan diantaranya tumor pada otak, multiple sclerosis, epilepsi, sindrom kelelahan kronis, parkinson, lupus, alzheimer, cacat mental, limfoma, kelainan pada kelahiran anak, dan bahkan diabetes. Salah satu tujuan penambahan pemanis sakarin pada minuman yaitu sebagai penambah rasa manis untuk mendapatkan tingkat kemanisan yang lebih tinggi sehingga dapat menekan harga.

Penelitian ini merupakan penelitian eksperimen atau percobaan di laboratorium, bertujuan untuk menganalisa suatu pemanis sintetis jenis sakarin pada minuman es kelapa muda yang dijual di Pasar Rajawali Kota Palangka Raya. Sampel yang digunakan dalam penelitian ini adalah es kelapa muda. Sampel diperoleh dari penjual es kelapa muda yang ada di Pasar Rajawali Kota Palangka Raya. Pasar Rajawali Kota Palangka Raya merupakan tempat berlangsungnya aktivitas jual beli yang dikunjungi banyak masyarakat setiap harinya. Di pasar ini, banyak pedagang yang menjual berbagai kebutuhan. Selain itu, di Pasar Rajawali Kota Palangka Raya terdapat beberapa macam kuliner makanan dan minuman, contoh kuliner minuman yang ada di Pasar Rajawali Kota Palangka Raya yaitu es jeruk, es kelapa muda, es campur, es buah, es teh, es dawet, dan jus buah. Sampel es kelapa muda dibawa ke Laboratorium Kimia Fakultas Ilmu Kesehatan Universitas 
Muhammadiyah Palangkaraya, untuk menganalisa zat pemanis buatan sakarin dengan menggunakan metode resorsinol. Identifikasi sakarin pada sampel minuman es kelapa muda dilakukan secara duplo (pengukuran berulang pada sampel yang sama) yang bertujuan untuk meningkatkan ketepatan dalam menganalisa.

Uji Kualitatif merupakan tahap awal yang dilakukan untuk mengidentifikasi sakarin dengan melihat reaksi perubahan warna yang terjadi pada sampel menggunakan pereaksi. Pemeriksaan ini dilakukan untuk mendapatkan hasil sampel positif atau negatif mengandung sakarin. Uji resorsinol pada analisis dilakukan dengan penambahan asam klorida dengan tujuan untuk mengubah garam sakarin dalam sampel menjadi asam sakarin yang tidak larut dalam air ${ }^{5}$. Sakarin akan larut dalam eter dan menyatu dalam lapisan eter. Lapisan eter diambil dan diuapkan di udara terbuka karena eter memiliki titik didih yang sangat rendah sehingga mudah menguap. Setelah eter menguap, tersisa residu yang kemudian ditambahkan 10 tetes $\mathrm{H}_{2} \mathrm{SO}_{4}$ pekat untuk memecahkan garam pada sakarin, kemudian dipindahka nkedalam tabung reaksi ${ }^{7}$. Setelah itu, ditambahkan dengan $40 \mathrm{mg}$ resorsinol dan dipanaskan secara perlahan-lahan dengan nyala api kecil sampai berubah menjadi warna hijau kotor. Tabung reaksi didinginkan lalu ditambah dengan I $\mathrm{mL}$ aquadest danl-5 tetes larutan $\mathrm{NaOH} \quad 10 \%$ berlebihan.Bila terbentuk warna hijau flouresensi berarti menunjukan adanya sakarin ${ }^{5}$. Prinsip dari uji resorsinol adalah sakarin akan memberikan warna hijau fluoresen jikadireaksikan dengan resorsinol dan $\mathrm{NaOH}$ berlebih ${ }^{8}$.

Pada penelitian ini sampel yang telah diuji tidak terbentuk warna hijau flouresensi maka dapat disimpulkan bahwa hasil analisis kualitatif pemanis buatan sakarin dengan menggunakan metode resorsinol yaitu 5 sampel minuman es kelapa muda yang dijual di Pasar Rajawali Kota Palangka Raya negatif mengandung sakarin. Tidak terdapat pemanis buatan sakarin pada sampel es kelapa muda yang telah diuji secara kualitatif menunjukkan bahwa penjual minuman es kelapa muda di Pasar Rajawali Kota Palangka Raya tidak menambahkan zat pemanis buatan sakarin pada dagangannya.

\section{KESIMPULAN}

Berdasarkan penelitian yang telah dilakukan dapat disimpulkan bahwa minuman es kelapa muda yang dijual di Pasar Rajawali Kota Palangka Raya tidak teridentifikasi mengandung sakarin.

\section{UCAPAN TERIMA KASIH}

Ucapan terima kasih kepada seluruh sivitas akademika yang telah membantu dalam proses Penelitian. Enumerator Penelitian yang meluangkan waktu dalam pengumpulan data. Pedagang es kelapa muda dan pengelola pasar rajawali sebagai tempat penelitian yang telah memberikan kesempatan.

\section{REFERENSI}

I. Cakrawati dan Mustika. 2012. Bahan Pangan, Gizi dan Kesehatan. Bandung: Al Fabeta.

2. Handayani, T. dan Agustina, A. 2015. Penetapan Kadar Pemanis Buatan (Na-Siklamat) pada Minuman Serbuk Instan dengan Metode Alkalimetri. Jurnal Farmasi Sains dan Praktis. I(I): I-7.

3. Murdiati, A. dan Amaliah. 2013. Panduan Penyiapan Pangan Sehat Untuk Semua. Jakarta:Kencana Prenadamedia Group.

4. Destyawati. 20I5. "Penentuan Kadar Sakarin pada Minuman Teh Kemasan".Jombang: Karya Tulis IlmiahSekolah Tinggi Ilmu Kesehatan Cendekia Medika.

5. Karolina, A.L. dan Rosmiati K. 2018. Uji Kadar Sakarin pada Minuman Ringan Bermerek yang Beredar diKota Pekanbaru. JurnalSains Dan TeknologiLaboratoriumMedik. 3(I): I4- 17.

6. Hartono, R. 20I4. "Identifikasi Siklamat pada Minuman Jajanan di Kawasan Pendidikan Kota 
Palangka Raya". Palangka Raya: Karya Tulis IlmiahUniversitas Muhammadiyah Palangkaraya.

7. Nasir, M. dan Idris, F. 2018. Identifikasi Sakarin pada Kue Buroncong yang Dijual di Kecamatan Panak kukang Kota Makassar. Jurnal Media Analis Kesehatan. 9(2):I36-I40.

8. Rohman, A. dan Sumantri. 2013. Analisis Makanan. Yogyakarta: Gadjah Mada University Press. 